\title{
ARTICLES
}

\section{AMERICAN SENSITIVITY TOWARD MONGOLIA}

\section{G H. Quester}

The average American knows very little about Mongolia, and in the future this may generate problems for the national interests of both countries. Even educated Americans are likely to guess, wrongly of course, that Mongolia was until 1991 a portion of the Soviet Union, or that it is today part of China, or that it has a huge population, etc. Very few Americans i. ${ }^{\mathrm{e}}$. are aware, for example, that a majority of ethnic Mongols live outside of independent Mongolia, and inside what is legally part of China.

Most importantly, the typical American has had much stronger positive feelings, over the past century and longer and somewhat greater knowledge, about China; and this can also be a source of some concern for Mongolia, a country of two million people resting next to 1200 million Chinese.

\section{America and China}

The American special tie to China is based on at least two factors, the major role played by American missionaries in China before the Communist takeover, and the great number- of Chinese who have come to the United States to become Chinese-Americans.

The American missionaries, more than in other parts of the world, reported back to their home congregations that the Chinese people were industrious and virtuous, burdened by corrupt and oppressive governments, but basically "people just like us", with a work ethic very much resembling the "Protestant ethic". Such missionaries may at times have deluded themselves about the depth and extent of such similarities, and about how many genuine converts they were making, as skeptics labeled the converts "rice Christians", i.e. Chinese who had converted only because this seemed an avenue to material gain. Yet many of the similarities the missionaries perceived and reported Yet many of the similarities the missionaries perceived and reported back to America were indeed real. The Chinese did revere work and education, something Americans similarly respected.

If one wishes to explain the American decision to confront Japan in the 1930s, a confrontation that ultimately produced the Japanese attack on Pearl Harbor, narrow considerations of U.S. national power, or the alleged needs of American capitalism, do not suffice. The United States was very concerned in 
the same years about the growing power of Nazi Germany under Hitler; elementary power-politics analysis suggests that one should not get into wars with two enemies at the same time. And American and other Western businessmen were not so vehemently opposed to the Japanese conquest of Manchuria or Northern China, seeing Japanese rule as a more business-like and trade-facilitating alternative to the Chinese warlords or Chinese Communists.

What instead brought the United States into World War II against Japan were the letters home from the American missionaries, recounting how horribly the Japanese were treating the Chinese, Chinese whom Americans had been brought to see as human beings with a similar set of values.

Reinforcing such imagery, of course, has been the presence of millions of Chinese-Americans, in successive waves of immigration. These have been victims of discrimination over and over again, accused by American workers of "working too hard" when the transcontinental railroads were built, and they are sometimes even today still the victims of mindless racial prejudices. But today the typical stereotype of Chinese-Americans, among Americans of European origin, is hardy negative. Rather it is the same as above, of people whose children study hard in school, and who work hard themselves, who engage less in crime than other minority groups, who succeed by the rules of the American free market system.

\section{America and Mongolia}

By contrast, the United States does not have any substantial MongolianAmerican population from which it can derive images of this country and culture*, and there was no major American missionary activity in the early nineteenth century in this part of the world.

Americans who know their history will remember that the Mongols under Chinggis Khan and Khubilai Khan almost conquered all of Europe, and did indeed conquer all of China, and only then to be conquered in turn by Chinese culture. This would set up an image of warrior ferocity and potentials for cruelty, contrary to what Americans impute to the Chinese. But most Americans are notorious for knowing almost no history at all, so that admiration for, or fear of, Khubilai Khan will not be a factor here.

In more recent history, Americans who know something of international affairs will instead remember Mongolia in much the same way that they remem-

\footnotetext{
*There is a small concentration of such people in New Jersey, but they will typically be mistaken by their neighbor: for Chinese.
} 
ber Manchuria, Xinjiang or Tibet, as territory that had been under a sort of Chinese imperial rule, and that had then been coveted by one foreign imperialist power or another. For all of the twentieth century, and even earlier, the United States, consistent with the positive pro-Chinese feelings noted above, has resisted any attempts to break up and partition "China", the attempts by Britain, France or Germany, and in particular the attempts by Russia and Japan.

This reflects very positive instincts in the American attitude toward the area, wanting to prevent the elimination of self-government in China, wanting to prevent any partition of East Asia such as one had seen in Africa or in the rest of Asia. But it again might work against the needs of Mongolia.

Just as the United States was later to oppose the Japanese establishment of a "Manchukuo" puppet state in Manchuria, it was thus opposed to Tsarist or Soviet Russian influence in Mongolia and Xinjiang, as it had also been opposed to French undermining of Chinese central government control in Yunnan, or British machinations in Tibet or the Yangtze valley.

When Mao Zedong's forces won control over ail of China, the United States used the phrase "Slavic Manchukuo" to refer to the new People's Republic of China. The phrase said a great deal about American feelings and values here, for it conveyed the accusation that the new China was "not really Chinese", was rather just as much a puppet and just as non-Chinese in its ideology and outlook and direction as the Japanese-sponsored regime in Manchukuo had been. The phrase conveyed that Americans were not hostile to things Chinese, but to foreign regimes imposed on the Chinese.

If anyone had asked, before 1948 and 1949, whether they could think of a Slavic equivalent of Manchukuo, the answer from someone who knew of Asian affairs might well have been Mongolia. The historical fact, which Mongols must face, is they won their independence as a result of what the outside world regarded as an expansion of Russian power, first Tsarist power before World War I, and then after 1921 as the Mongolian People's Republic became Stalin's first satellite. Just as with all the other "people's republics" established under Moscow's dictation after 1945, Americans were disinclined to see this as authentic reflections of popular will. Just as with the Japanese attempt to mint up new political units in what had been China, an emphasis on "independence" for Mongolia looked like an attempt to conquer China by breaking it into pieces.

In short, the American desire to protect China against Japanese or Slavic imperialism was thus to lean toward reinforcing Chinese imperial authority. The reason the United States had to wait so very long to establish normal diplomatic relations with Mongolia was that, until it transferred its diplomatic recognition 
from the Republic of China on Taiwan to the People's Republic of China in Beijing, it was still in effect accepting the Republic of China's claims as to what the extent of China is, including Mongolia.

Chinese Communist spokesmen, irritated at what continues of American support for Taiwan, often accuse Americans of wanting to divide China. Nothing could be further from the truth, as Americans admire all things Chinese, and as they have a history, culminating in the sacrifices of World War II, of resisting the "division of China".

Mongols, as well as Tibetans and Vietnamese, can rightly protest that this under-informed American view of the region may blind Americans to the dangers of Chinese imperialism. In protecting China against Western imperialism, Americans may be forgetting how much the nationalities peripheral to the "Central Kingdom" have resented Han chauvinism.

Relatively few Americans are thus aware that Mongols have not used Chinese characters to write their language in the past, as have the Japanese to this day, and as used to be the practice in Korea and Vietnam. Vietnamese resent being lumped into the Chinese cultural sphere by Americans, but the nomenclature of the past - French Indo-China - and the lifestyle one sees, in Hanoi or Saigon ail suggest that they have a great deal in common with the Chinese. Very few Americans come to Ulaanbaatar, which is symptomatic of the perceptual problem we are discussing here, and thus very few can see how much the Mongolian urban style differs from that of a Chinese, or Vietnamese or Korean, city.

\section{Some Possible Countertrends}

Americans are not really interested in discovering new ethnic complexities in East Asia. If someone wishes to explain the characteristics of all the non-Han minority groups inside China, the typical American reacts to this with the same dismay that he felt in discovering how many different kinds of "Yugoslavs" there are. To learn about "Bosnian Muslims" and "Croats" and "Macedonians" and "Slovenians" has, for most Americans, come as an introduction to a brutal and unanticipated new round of ethnic strife after the Cold War. It is thus always reassuring when Americans are told that the overwhelming majority of the 1200 million inhabitants of the People's Republic of China are Han in culture, feeling strongly unified in this culture and its written language, even if they pronounce it in so many different ways.

The typical American reacts to it as good news that the people in Shandong, Shanghai, and Hong Kong are all "Chinese". He would probably regard it as equally happy news if, contrary to fact, he were told that the Tibetans and 
Mongols were also Han, for this would be that much less to worry about in the future on ethnic conflict and ethnic cleansing, i.e., on the fractionation of what had been unified countries.

Yet there are Americans who identify with the grievances of Tibetans against the Chinese. Where does this American sentiment stem from, and what does it suggest for the case of Mongolia? In important part, this is based on what we have already mentioned above, the strong American respect for religion.

Communist China still pretends to be atheist in its outlook and opposed to religion, although the restraints on religion are much less than they used to be, with the result that Christianity, Islam and Buddhism are booming again across China. Many Tibetans who oppose Chinese rule support the Dalai Lama and a return to the peculiar kind of Buddhist theocracy which governed Tibet before Communist assertions of power in the 1950s.

An objective observer might note that this rule by Buddhist monks was quite backward-looking and cruel in the punishments it inflicted, so that the imposition of Chinese Communist rule could be seen as an achievement of modernity. But there are Americans, of whom Senator Jesse Helms is a very important example, who will almost instinctively defend any religion against any atheistic Communist regime.

Americans became attached to China in important part through a desire to spread the Christian religion. Like any religions around the world, they tend to respect almost any religion ahead of an outright opposition to religion. If the Tibetan desire for independence from China were based on anything but religion, there would probably at this stage be less American interest.

American support for Tibetan independence, or even Tibetan autonomy, produces a tremendous resentment in China, second only to, or perhaps even ahead of, American support for Taiwan. And it is interesting to note that the Chinese on Taiwan, along with pro-democracy Chinese students exiled in the United States, also tend very much to dismiss the case for Tibetan independence.

Perhaps Chinese everywhere are thus chauvinist nationalists, looking down on other cultures as inferior to their own Han culture. Or perhaps it is instead that they still have the bitter memories of the separations of Tibet, Manchuria or Taiwan inflicted in recent history, seemingly the first steps to the foreign conquest of all of China. The bristling Chinese cultural nationalism, of which Marx and Lenin would surely have disapproved, may thus be an independent phenomenon, or a simple defensive reaction. Either way this can generate problems for the United States and for Mongolia. 
China has twice recognized the independence of Mongolia, and for each case the Mongols must give their thanks not to the United States but to Joseph Stalin.

Chiang Kai-shek was pressured by Stalin to make such a concession in 1945, in the agreements defining future Sino-Soviet relationships. The Kuomintang was then to renounce this in 1949 when it was driven to Taiwan claiming that Stalin had facilitated Mao's victory and thus had forfeited any claims he had under these agreements. To this day the "Republic of China" on Taiwan claims sovereignty not only over Mongolia but even Tannu Tuva. It agrees with Beijing on all other Chinese border claims, such as those involving India, Vietnam, and Burma as well as disputes in the South China Sea.

Mao's People's Republic of China recognized the independence of Mongolia in 1949, but one again wonders, especially when the comparison is made with Tibet, whether Mao would have done this if Stalin had not insisted upon it. Whenever one even broaches the independence of Tibet with anyone in Beijing, one gets lines of argument in response that would apply equally much to Mongolia, that "this has always been part of China", that "it was only wrested away by the machinations of imperialism", that "the people are better off sharing in the benefits being achieved in the unity of China".

China's official statements still remain correct on the independence of Mongolia. But Mongols claim to know of schoolbooks and lectures in Chinese schools that state that Mongolia is rightfully part of China. Moreover, another three million Mongols already live as a minority inside China in "Inner Mongolia" where the Chinese claim they live as a "protected ethnic minority" with special privileges, like being exempted from the one-child policy. Under these conditions, it is no wonder that the two million Mongols in independent Mongolia are sensitive to. Analogies between their own situation and that of Tibet.

\section{Policy Avenues for Mongolia}

The suggestions for Mongolian policy that emerge from this analysis would seem fairly straightforward. It is to everyone's interest to encourage Americans to visit Mongolia, and to get to know more about the country. Over time, a relationship of identification could develop here as it has between China and the United States.

Given the American concern for religion, some of the earliest Americans coming to Mongolia are indeed again missionaries. It is surely to Mongolia's interest to advertise the renewal of religion it is experiencing, as the restraints on worship have been lifted, and the number of Buddhist monasteries has been 
dramatically increased. Just as some Americans are interested in exporting various kinds of Christianity to the entire world; other Americans are interested in importing Buddhism to the United States. A focus on either kind of interchange enhances the identification Americans would feel for Mongolia.

At the same time, given Chinese sensitivities, it would be a mistake for Mongolia to advertise or stress any parallels with Tibet. Thanks to Stalin, the Chinese renounced their sovereignty over Mongolia in a manner that we may not see for another century for Tibet or Taiwan. However much the ethnic realities might suggest parallels between Mongolia and Tibet, the accident of history offers a discontinuity to be exploited.

This raises the question again of what the regime on Taiwan has to say about Mongolia. Any Mongolian economic or other links with Taiwan have, of course, to be approached very carefully, given Beijing's sensitivities. Yet a growth in such links would seem almost inevitable, when one simply looks at the amount of Taiwan investment in Communist China. In light of this, it would indeed be useful to get the "Republic of China" in Taipei, very gradually and in a very subtle manner, to stop claiming Mongolia for China.

\section{Policy Avenues for the United States}

The United States will favor the independence of Mongolia not because it looks for opportunities to divide, weaken or contain China, but because the Mongols are indeed a separate people. Given the genuine commitments to selfdetermination, the United States should also exploit Stalin's accomplishment here, that China officially does not contest Mongolian independence.

With regard to all the analogous examples of Chinese touchiness on such issues, the real lesson for American policy is most probably one of patience, as it will take time for the Chinese to relent on their extravagant claims to the Sprightly Islands in the South China Sea and time for them to allow Tibet some real autonomy or independence, and a great deal of time for the political reforms of China itself to mature enough that the Chinese on Taiwan might see no point in having a separate and independent political system.

In the best future one could imagine, all of China would be politically free, economically prosperous, and unified while Tibet and Mongolia would be independent, with no one in China seeing this as a threat. But this is a matter for decades or centuries rather than for quick solutions.

Mongols and Americans will share substantial interests and concerns as this slow and painstaking process is completed. 